\title{
The current status in the silicon crystal growth technology for solar cells
}

\author{
A-Young Lee, Dong-Gue Lee and Young-Kwan $\mathrm{Kim}^{\dagger}$ \\ Department of Materials Science and Engineering, Incheon National University, Incheon 406-772, Korea \\ (Received January 17, 2014) \\ (Revised April 8, 2014) \\ (Accepted April 14, 2014)
}

\begin{abstract}
Three kinds of crystalline silicon have been used for the solar cell grade. First of all, single crystalline silicon is the main subject to enhance the production yield. Most of the efforts are focused on the control of the melt-crystal interface shape affected by the crystal-crucible rotation rate. The main subject in the multi-crystalline silicon ingot is the contamination control. Faster Ar gas flow above the melt surface will lower the carbon contamination in the crystal. And also, twin boundary electrically inactive is found to be more effective than grain boundary for the improvement of the MCLT. In the case of mono-like silicon material, propagation of the multi-crystalline silicon growing from the inner side crucible is the problem lowering the portion of the single crystalline part at the center of the ingot. Crystal growing apparatus giving higher cooling rate at the bottom and lower cooling rate at the side crucible was suggested as the optimum solution obtaining higher quality of the mono-like silicon ingot. Proper application of the seeds at the bottom of the crucible would be one of the solutions.
\end{abstract}

Key words Crystalline silicon solar cell, Single crystalline Si, Multi-crystalline Si, High efficiency, Mono-like Si

\section{태양전지용 규소 결정 성장 기술 개발의 현황}

이아영, 이동규, 김영관

인천대학교 신소재공학과, 인천, 406-772

(2014년 1월 17일 접수)

(2014년 4월 8일 심사완료)

(2014년 4월 14일 게재확정)

요 약 태양전지용 규소에는 단결정, 다결정, mono-like의 세 가지 재료가 사용 중에 있다. 첫 번째로, 단결정은 수율 향상의 과제에 집중되고 있으며, 이것은 고액 계면의 형상이 주요 요인으로 알려지고 있다. 이에 대한 연구가 전산모사 등 으로 집중되고 있다. 또한 결정과 도가니의 회전 속도가 고액 계면의 형상에 영향을 미치는 것이 확인 되었다. 다결정의 경우에는 결정립계의 역할이 매우 중요하므로 이에 대한 연구가 진행되는데, 이들을 특히 전기적으로 비활성적인 쌍정 입 계로 전환하는 연구가 진행되고 있다. 성장 조건을 변경시켜 쌍정 입계로 바꾸어서 재료의 전기적 성질을 향상시키는 결과 를 확인하였다. 또한 성장 공정에서 발생될 수 있는 오염을 줄이기 위한 노력은 상부의 $\mathrm{Ar}$ 가스의 흐름을 상향 조절하여 불순물의 용입을 줄임이 확인되었다. 다음으로 mono-like인 경우에는 측면으로부터 성장 되어 들어오는 다결정이 단결정의 분율을 저하 시키는 주요 요인이 되고 있다. 이에 대한 해결책으로 하부의 냉각 속도를 높이고 상부와 측면에 단열재를 보 강하는 방안이 제시되고 있고, 하부에 놓는 seed의 orientation을 조절하여 측면으로부터 성장 되어 들어오는 다결정을 억제 하는 방안이 효과가 있음이 확인 되고 있다.

1. 서

$\mathrm{PV}$ 산업에서 널리 상용되고 있는 규소 결정계 태양전 지에는 단결정과 다결정이 있다. 단결정 규소는 웨이퍼

\footnotetext{
Corresponding author

Tel: +82-10-3375-4050

Fax: +82-32-835-0778

E-mail: youngkim@incheon.ac.kr
}

내에 결정립계가 존재하지 않는 하나의 결정립으로 이루 어져 있어 내부에서 빛에 의해 여기된 전자의 이동이 용 이하며, 다결정 규소보다 효율이 높다. 하지만 단결정 잉 곳을 생산하기 위해서는 단결정 규소 seed를 이용한 Czochralski method(이하 $\mathrm{CZ}$ 법)로 오랜 시간 동안 천천 히 성장시켜야 하기 때문에 생산 단가가 높다. 또한 boron으로 도핑된 p-type 태양전지에서 주로 발생되는 LID(Light Induced Degradation) 효과에 영향을 미치는 
산소 석출을 감소시키기 위해 $\mathrm{Si}_{3} \mathrm{~N}_{4}$ 로 코팅한 도가니를

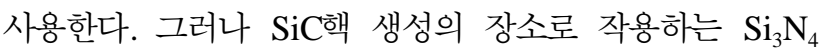
입자들로 인해 단결정을 훼손시킬 뿐만 아니라 MCLT (Minority Carrier Lift Time)를 감소시킨다[1]. 이러한 단결정 규소의 단점들 때문에 다결정 규소의 수요가 증 가하고 있지만, 여기된 전자를 재결합시켜 흐름을 방해 하는 결정립계로 인하여 광전 변환 효율이 감소되는 문 제점이 있다[2]. 하지만 생산 속도 및 수율, 생산 단가 등에서 단결정보다 우수한 점이 많기 때문에 보편적으로 많이 사용되고 있으며, 세계적으로 다결정 태양전지의 생산량 $(60 \%)$ 이 단결정 태양전지의 생산량 $(40 \%)$ 보다 많다[3]. 다결정 규소 잉곳은 일반적으로 Directional Solidification Method(이하 DS법)으로 생산하며 CZ법에 비해 대용량 생산이 가능하다.

최근에는 단결정의 장점인 고효율과 다결정의 장점인 낮은 생산 단가를 융합시키는 연구 개발이 활발히 이루 어지고 있다. 그 일환으로 mono-like 규소에 대한 개발 이 진행 중이다. Mono-like 규소는 기존의 다결정 성장 장비를 사용하여 mono-like 규소 잉곳에 맞는 조건들로 변경해준다면 기존 공정을 그대로 유지하여 성장시킬 수 있다. 그러나 도가니 측면으로부터의 핵 생성으로 인한 다결정 성장 억제가 어려워 mono-like 규소의 단결정 분율이 감소되어 수율이 떨어지는 단점이 있다[4].

본 연구에서는 태양전지용 결정질 규소 제조방법의 최 신 연구 동향을 조사하여, 앞으로 나아가야 할 규소 결 정계 태양전지의 방향에 대해 제시해보고자 한다.

\section{2. 규소 결정 성장 기술}

\section{1. 단결정 성장}

일반적으로 $\mathrm{CZ}$ 법을 통해 제조되는 단결정 규소는 높 은 생산 단가, LID효과, 낮은 수율 등으로 인해 다결정 규소의 효율보다 높음에도 불구하고 시장 점유율이 낮다.
그 중에서도 공정 중 발생되는 결함에 의한 낮은 수율은 생산 단가를 증가시키는 결과를 야기시키며, 이것은 PV 산업에서 큰 문제점으로 대두되고 있다. 따라서 열 응력 과 오염 제어 등을 통한 수율 향상의 노력이 필요하며, 그 방법들에 대해 알아보도록 하겠다.

\subsection{1. 열 응력 제어}

열 및 물질 전달과 규소 melt의 온도장에 중요한 역할 을 하는 melt 대류는 고액 계면 형상과 온도 구배에 영 향을 끼치며, 이것에 의해 결함, 열-탄성 응력, 불순물 분배가 제어된다. 고액 계면의 형상과 온도 구배는 도가 니의 위치 및 기울기, 결정과 도가니의 회전율에 따라 달라진다[5-7]. 심 복철 등에 의하면 melt level(M/L)이 낮을수록 melt 대류가 증가하며, 계면의 형상이 결함 발 생에 영향을 미친다고 보고하고 있다[6].

노르웨이의 Noghabi 등은 전산모사를 통해 계면의 형 상에 영향을 끼치는 결정과 도가니의 최적의 회전율 조 합을 연구하였다. 그 결과, 결정이 5 10 rpm으로 회전할 때에 계면의 굴절이 최소가 되며 결정화 구역으로부터 방출되는 열을 막아준다. 그리고 도가니의 회전율이 $15 \mathrm{rpm}$ 일 때에 계면의 굴절이 최소가 된다. 계면의 굴절 을 중요시하는 이유는 최대 굴절을 가지는 위치에서 열탄성 응력의 강도가 증가하기 때문이다. 이것은 계면의 형상과 상호관계에 있으며, 높은 굴절률을 가지는 $\mathrm{W}-$ shape 계면은 전위 발생의 근원이 된다. 따라서 위에서 언급된 결정과 도가니의 최적 회전율로 결정을 성장시킨 다면 결함 및 열-탄성 응력을 감소시킬 수 있다[7].

\subsection{2. 오염 조절}

Boron으로 도핑된 p-type 단결정 규소 성장 시에 유입 되는 산소는 B-O complex를 형성하여 LID 문제를 야기 시킨다. 한 연구에 의하면 $\mathrm{CZ}$ 법으로 키운 단결정 규소에 서의 효율이 $17.9 \%$ 이고 $\mathrm{QSC}$ (Quasi-single crystalline) 규소에서의 효율은 $17.3 \%$ 로 낮다. 그러나 단결정 규소 에서 B-O complex의 형성으로 인하여 효율 감소가 $2.1 \%$
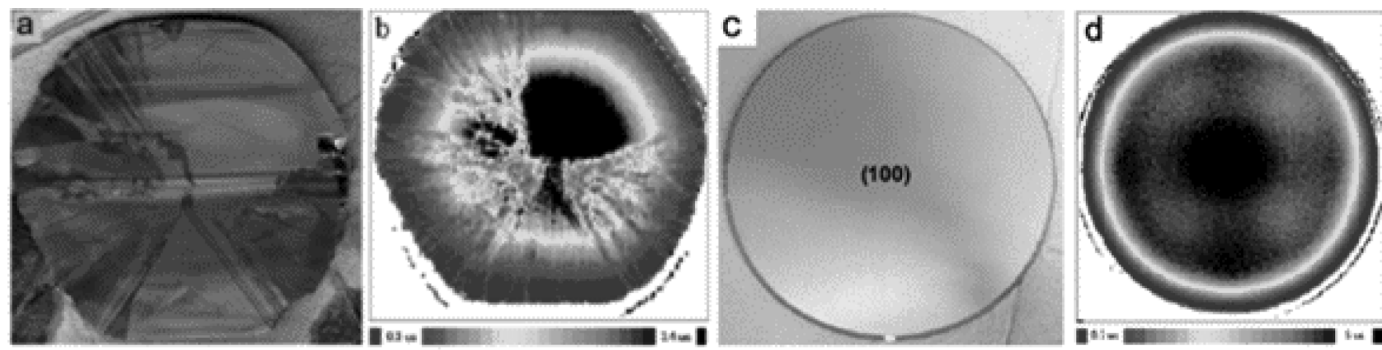

Fig. 1. (a) Cross section of the ingot with many small grains and one large grain (b) Distribution of minority carrier lifetime in the same cross section (Most regions have a low minority carrier lifetime, and only the large grain has a high minority carrier lifetime.) (c) Cross section of the ingot. No grain boundaries are observed in the cross section. (d) Distribution of the minority carrier lifetime in the same as-cut cross section. The distribution of the high minority carrier lifetime is almost uniform except for the growing pattern. 
인 반면, QSC 규소는 $0.4 \%$ 로 5 배가 넘는 차이를 보인 다[8]. 이와 같이 산소 유입으로 인한 효율 감소를 해결 하기 위해서 일본의 Nakajima 등은 고액 계면에 온도가 낮은 지역을 생성하여 대류를 억제시켜 산소 농도를 감 소시켰다. 보편적으로 melt 내의 산소 유입을 막기 위하 여 $\mathrm{Si}_{3} \mathrm{~N}_{4}$ 로 코팅된 도가니를 사용하는데, 이 경우에는 melt의 표면에 $\mathrm{Si}_{3} \mathrm{~N}_{4}$ 입자들이 떠다니며 핵 생성을 유도 한다. 그에 따라 Fig. 1(a and b)와 같이 결정립이 많이 생성되며 MCLT를 감소시킨다. 따라서 이들이 연구한 noncontact crucible 방법으로 $\mathrm{Si}_{3} \mathrm{~N}_{4}$ 로 코팅하지 않은 도 가니를 사용하여도 Fig. 1(c and d)와 같이 하나의 결정 립을 갖고 $\mathrm{MCLT}$ 값을 높이면서 산소의 유입을 감소시 킬 수 있다[1].

\section{2. 다결정 성장}

$\mathrm{PV}$ 산업에서 점유율이 높은 다결정 규소는 $\mathrm{DS}$ 법으로 낮은 비용으로 대용량 생산이 가능하지만, 많은 결함 때 문에 단결정 보다 효율이 낮다. 따라서 효율을 향상시키 기 위한 노력이 필요하며, 향상시킬 수 있는 방법은 다 음과 같다.

\subsection{1. 결정립계 조절}

다결정의 질을 떨어뜨리는 결정 결함들은 소수반송자 의 재결합을 유도하여 효율을 감소시킨다. 결정 결함들 중, 면 결함인 결정립계는 높은 에너지를 가지고 있어
불안정한 상태이기 때문에 전자의 이동을 방해하여 효율 을 감소시킨다. 그러나 모든 결정립계가 MCLT를 감소 시키는 것은 아니다. $\Sigma 3$ 결정립계( $\Sigma$ 는 regular lattice에 대한 coincidence site lattice의 비), 특히 쌍정 입계는 전기적으로 비활성화하여 전자의 이동을 방해하지 않으 며 잔류 응력과 전위 밀도를 감소시킬 수 있다. 이 쌍정 입계를 얻기 위해 벨기에의 Xiaohui Tang 등은 원하는 결정립 방향과 결정립계를 얻기 위해 결정립 구조를 제 어할 수 있는 그들만의 기술로 S2라 불리는 새로운 다 결정 규소를 성장시켰다. S2는 Fig. 2와 같이 기존 다결 정 규소보다 에너지가 낮은 $\Sigma 3$ 결정립계가 많이 존재하 며, 평균 $0.62 \%$ 의 효율 증가 등 웨이퍼의 전기적 특성 에 영향을 끼친다[3].

일본의 Nakajima 등은 $\mathrm{Si}_{3} \mathrm{~N}_{4}$ 로 코팅되지 않은 도가니 와 necking 기술을 사용한 seed를 적용하고 crucible noncontact 기술을 이용하여 Fig. 3(a and b)와 같이 쌍정 입계와 크기가 큰 결정립을 얻었다. 이 잉곳의 MCLT는 Fig. 3(c)와 같으며, seed가 있는 중심부에서 $6.9 \mu \mathrm{s}$ 의 최 대값을 보였지만 작은 영역을 차지하는 $\mathrm{Si}_{3} \mathrm{~N}_{4}$ 입자로 인 해 MCLT가 감소된 것을 볼 수 있다. 따라서 이 연구에 서는 핵 생성의 근원을 없애기 위해 $\mathrm{Si}_{3} \mathrm{~N}_{4}$ 로 코팅되지 않은 도가니를 사용하였으며, crucible noncontact 기술 로 결정내의 산소 농도를 감소시켰다[9].

그리고 결정립계의 수를 줄이기 위해 일본의 Fujiwara 등은 냉각 온도를 증가시켜 Fig. 4(b)와 같이 <110>으로 의 성장을 유도하여 크기가 큰 결정립을 얻었다. 또한
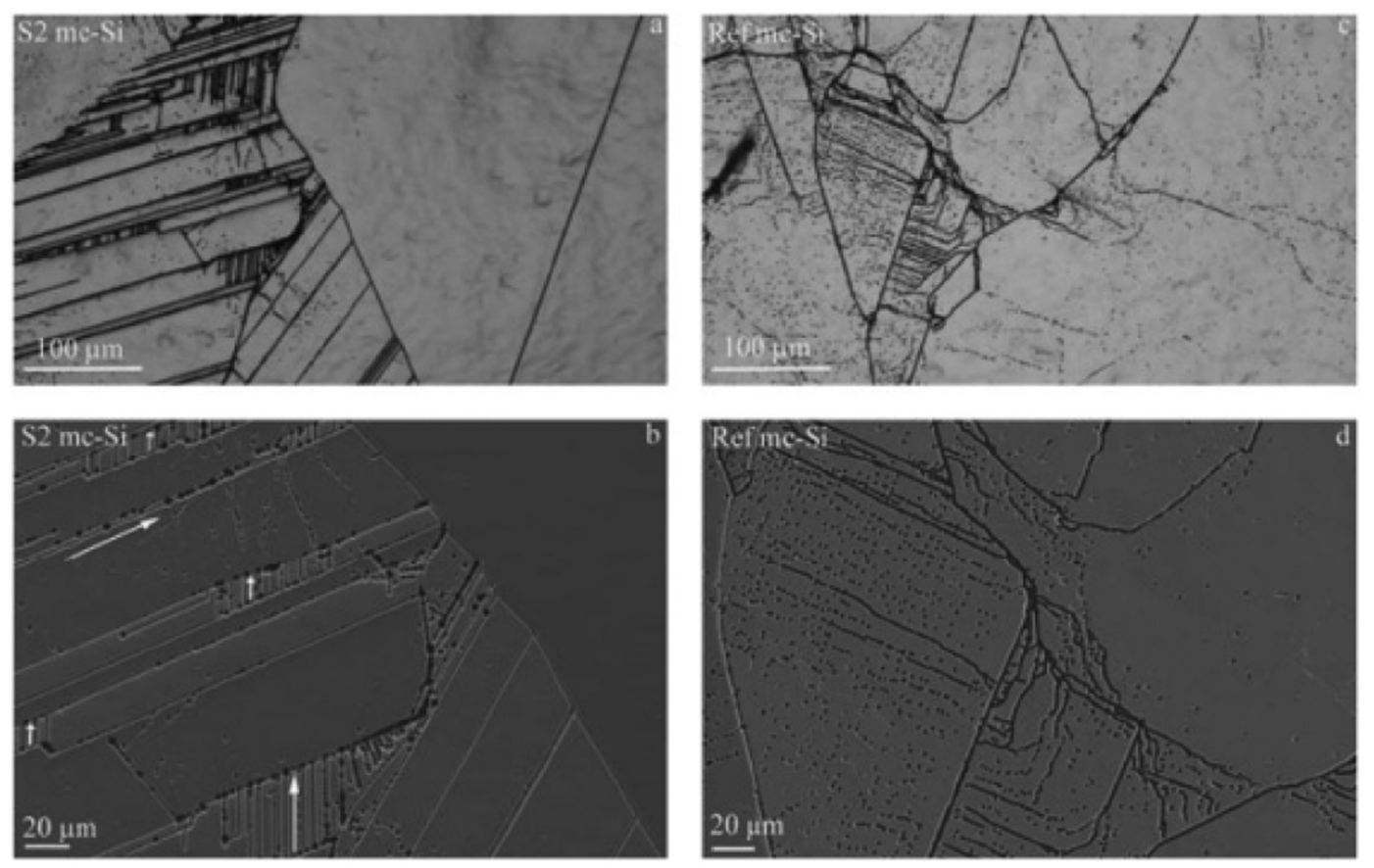

Fig. 2. A typical dislocation region for a S2 mc-Si wafer (a) light image and (b) scanning electron microscope image, arrows appear as parallel straight lines showing electrically inactive twin boundaries. A typical dislocation region for a Ref mc-Si wafer (c) light image and (d) scanning electron microscope image. 


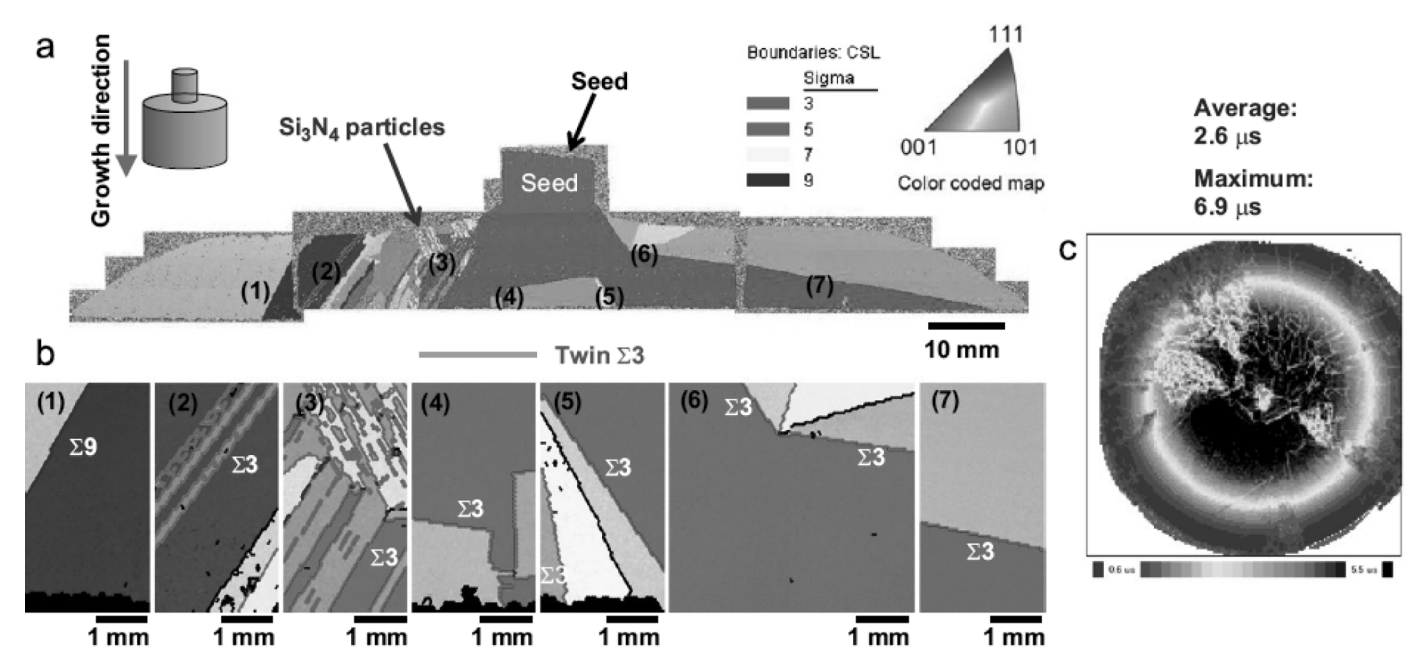

Fig. 3. (a) Orientation EBSD pattern image map of a vertical cross section cut at the center of the top of the ingot shown in Fig. 4(a). This map shows the crystallographic orientation of grains perpendicular to the (100) growth direction of the ingot. (b) Enlargements of parts of the EBSD pattern image map in (a) labeled 1 7 along with the characteristics of the grain boundaries. The cutting position is indicated by the yellow line in Fig. 4(a). The area where $\mathrm{Si}_{3} \mathrm{~N}_{4}$ particles appeared is shown by a blue arrow.

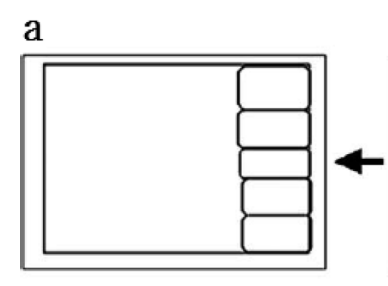

Fig. 4. (a) Directional growth of poly-Si from a melt cooled at $1 \mathrm{~K} / \mathrm{min}$. The white lines in the growing crystal are grain boundaries. (b) Directional growth of poly-Si from a melt cooled at $50 \mathrm{~K} / \mathrm{min}$. A grain rapidly grew along the sidewall of the crucible in the initial stage of growth.
성장한 결정립은 대부분 (112)로 일정한 방향의 면을 얻 어, 그렇지 않은 잉곳의 효율보다 $0.8 \%$ 더 높은 결과를 이끌어내었다[10].

\subsection{2. 불순물 제어}

다결정 규소에서 불순물 중의 하나인 탄소는 $1 * 10^{16}$ atom $/ \mathrm{cm}^{3}$ 의 농도를 초과하면 산소가 석출되어 불순물의 intrinsic gettering 장소로 작용하고 기계적 강도에 영향 을 미친다. 또한 농도가 용해도를 초과하면 $\mathrm{SiC}$ 로 석출 되어 ohmic shunt를 발생시키고 새로운 결정립의 핵 생 성을 초래한다. 이러한 탄소의 농도를 감소시키기 위해 일본의 $\mathrm{Gao}$ 등은 강한 대류 흐름을 이용하여 대기중의 $\mathrm{CO}$ 가 melt 안으로 이동하는 것을 줄이는 연구를 하였다. 이들은 melt 표면에서부터 가스 튜브 덮개까지의 거리 $\mathrm{h}$ 에 따른 대류 흐름의 강도에 대해 전산모사를 하였다. 그 결과, $\mathrm{h}$ 가 감소할수록 대류 흐름의 강도가 강해지면 서 melt 안으로의 탄소 흐름을 억제할 수 있었다[11].

탄소 및 산소의 농도는 전기로 내의 graphite 부품에 의해서도 증가할 수 있는데, 독일의 Raabe 등이 graphite 부품의 설치 유무에 따른 $\mathrm{CO}$ 농도를 측정해 보았다. 그
결과, Fig. 5과 같이 graphite 부품이 설치되지 않은 조 건에서는 $\mathrm{CO}$ 의 농도가 현저히 작았지만, graphite 부품 을 설치하면 $\mathrm{CO}$ 농도가 증가하며 표면에 $\mathrm{SiC}$ 층을 형성 시켰다. 그와 반대로 graphite 부품을 설치하지 않고 성 장시킨 잉곳은 표면이 빛날 뿐만 아니라 몇몇의 $\mathrm{SiC}$ 석 출 이외에는 거의 순수한 규소 상태의 표면을 가졌다. 따라서 대기중의 $\mathrm{CO}$ 농도를 감소시킴으로써 잉곳 표면 에서의 불순물 제어가 가능하다는 것을 입증하였다[12].

이외에도 일본의 Matsuo 등은 전위, stacking fault와 B-O complexes로 인한 LID 효과를 발생시키는 산소 석 출을 억제하기 위하여 $\mathrm{Si}_{3} \mathrm{~N}_{4}$ 로 코팅된 도가니를 사용하 고 melt 표면으로 $\mathrm{Ar}$ 가스를 흘려 보내어 melt 내의 산 소 농도를 감소시키는 노력을 하였다[13].

\subsection{Mono-like 규소 결정 성장}

단결정과 다결정 규소의 장점만을 겸비한 mono-like 규소는 $\mathrm{CZ}$ 법, $\mathrm{DS}$ 법 등으로 성장시킬 수 있다. 그러나 CZ법으로 생산되는 mono-like 규소는 효율이 다결정 규 소의 효율에 비해 1 2\% 정도 밖에 높지 않아 공정 시 

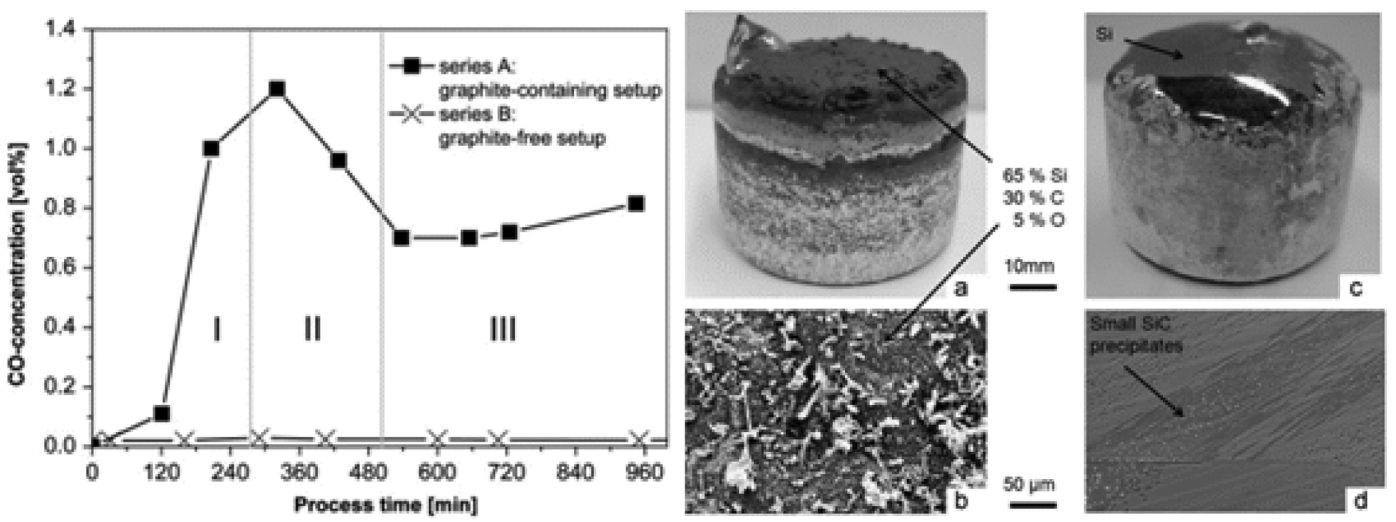

Fig. 5. CO concentration proles in growth with and without graphite components in the furnace: I-heating, II-melting/homogenisation, and III-directional solidication. (a and c) Photos of crystals grown in graphite-containing (left) and graphite-free setup (right). (b and d) SEM images of top surfaces of crystals shown above. The composition of the surface layer and surface precipitates were analysed by means of EDX.

간 및 비용 등의 손해가 발생한다[14]. 이로 인하여 $\mathrm{BP}$ Solar 사에서 DS 법을 이용하여 mono-like 규소 결정을 성장시키는 방법을 개발하였다[15]. 하지만 성장 과정 중에 도가니 측면으로부터의 핵 생성이 단결정 분율에 악영향을 미쳐 mono-like 규소 결정 개발에 장애 요소 가 되고 있는 실정이다. 따라서 여러 가지의 연구들이 수행되고 있으며, 다음 내용과 같다.

\subsection{1. 수율 향상}

다결정 규소를 생산하는 장비로 동일한 공정을 적용하 여 mono-like 규소 결정을 생산할 경우, seed의 과다 용 융으로 인한 잉곳 내부의 단결정 형성이 어려워질 수 있 다. seed로부터 잉곳 성장 방향으로 단결정 형성 및 분 율 향상을 위해서는 기존 장비의 hot zone 재설계가 필
요하다. 일본의 $\mathrm{Gao}$ 등이 실험하였던 전산모사를 통한 hot zone 재설계 결과에 따르면, 도가니의 상부와 측면 에 단열재를 보강하고 하부로부터의 냉각을 증가시키면 seed의 과다 용융을 방지하고 단결정 분율을 향상시킬 수 있다. 또한 hot zone 재설계를 통하여 도가니 측면에 서의 핵 생성으로 인한 다결정 성장을 억제할 수 있기 때문에 mono-like 규소 결정 성장에서 매우 유용한 예 측 결과라 할 수 있다[16, 17].

또 다른 수율 향상 방법으로 seed의 orientation을 조절 하는 연구가 일본의 K. Kutsukake 등에 의해 발표되었다. 이 연구 결과에 따르면 도가니 측면으로부터 결정 내부 로 뻗어나가는 결정립계가 seed로부터 뻗어나가는 결정 립계를 만나 내부로의 진행이 억제되며, 이로 인하여 잉 곳 내의 단결정 분율이 향상될 수 있다고 주장한다[4].

Table 1

Summary of technology development

\begin{tabular}{|c|c|c|c|}
\hline & Advantage & weakness & Solution \\
\hline Single crystalline & - High efficiency & $\begin{array}{l}\text { High production cost } \\
\text { - LID effect } \\
\text { - Difficulty of defect } \\
\text { control }\end{array}$ & $\begin{array}{l}\text { Thermal stress control } \\
\text { - Position and tilt control of crucible }[5,6] \\
\text { - Combination of crystal-crucible rotation rate [7] } \\
\text { - Contamination control } \\
\text { - Application of crucible noncontact technology [1] }\end{array}$ \\
\hline Multi-crystalline & $\begin{array}{l}\cdot \text { Low production } \\
\text { cost } \\
\cdot \text { High-capacity } \\
\text { production }\end{array}$ & $\begin{array}{l}\text { Reduction of } \\
\text { efficiency by defect }\end{array}$ & $\begin{array}{l}\text { - Grain boundary control } \\
\text { - Increase of } 3 \text { grain boundary density [3] } \\
\text { - Application of crucible noncontact technology [9] } \\
\text { - Increase of cooling temperature [10] } \\
\text { - Impurity control } \\
\text { - Reduction of atmospheric CO transport [11] } \\
\text { - Disuse of graphite component [12] } \\
\text { - Use of } \mathrm{Si}_{3} \mathrm{~N}_{4} \text { coated crucible [13] }\end{array}$ \\
\hline Mono-like Si & $\begin{array}{l}\text { - Low production } \\
\text { cost } \\
\text {. High efficiency }\end{array}$ & $\begin{array}{l}\text { Reduction of single } \\
\text { crystal fraction by } \\
\text { nucleation from side } \\
\text { crucible }\end{array}$ & $\begin{array}{l}\text { - Hot zone design }[16,17] \\
\text { - Insulator supplement and cooling increase at bottom } \\
\text { - Seed orientation control [4] } \\
\text { - Heat loss control } \\
\text { - Installation of insulation partition at heat loss part [18] }\end{array}$ \\
\hline
\end{tabular}




\subsection{2. 열 손실 제어}

Mono-like 규소를 성장시킬 때 전기로 내부에서의 온 도 구배, 즉 도가니가 아래로 하강함에 따라 전기로 내 부의 열이 외부로 빠져나가는 것에 대한 조절이 잘 이루 어져야 안정적으로 결정이 성장될 수 있다. 중국의 W. $\mathrm{Ma}$ 등은 열 흐름을 조절하기 위해 내부의 열이 외부로 빠져나갈 수 있는 통로에 단열 칸막이를 설치하여 전기 로 내부의 온도 구배에 변화를 주었다. 설치된 단열 칸 막이는 전기로 내부의 온도 구배뿐만 아니라 전기로의 열손실의 감소 또한 가능하다. 따라서 전기로 내부의 열 손실을 억제함으로써 잉곳이 안정적으로 성장될 수 있으 며, 생산 단가를 낮출 수 있다고 예상된다[18].

\section{3. 결 론}

1) 단결정의 경우, 수율 향상을 위해 고액 계면의 형상 관리가 필요하다. 이를 위해 최적의 결정 및 도가니 회 전율을 찾아 공정에 적용하거나, 잉곳의 전기적 특성에 영향을 끼칠 수 있는 불순물 및 전위 등을 제어해야 한다. 또한 LID 향상을 위해 산소 농도 저감에 대한 crucible noncontact 기술과 같은 노력을 하였다. 그러나 melt의 오염 조절을 위하여 $\mathrm{Si}_{3} \mathrm{~N}_{4}$ 코팅된 도가니의 사용 은 단결정을 훼손할 가능성이 높은 것으로 판단된다.

2) 다결정의 경우, 효율 향상을 위해 결함 밀도가 높은 결정립계는 줄이고 전기적으로 비활성화되어 있는 쌍정 입계를 늘이거나, 전기로 내부에서 발생되는 탄소의 유 입을 막을 수 있는 $\mathrm{Ar}$ 가스의 주입으로 규소 melt 내의 불순물 농도를 제어하는 노력들이 이루어지고 있다.

3) Mono-like 규소의 경우, 단결정 분율의 향상을 위 해 기존 다결정 성장 장비의 hot zone 재설계를 통하여 도가니 측면에서의 핵 생성으로 인한 다결정 성장을 억 제하거나, seed의 orientation을 조절하여 도가니 측면으 로부터 결정 내부로 뺃어나가는 결정립계를 제어하였다. 또한 전기로 내부의 열 손실을 억제함으로써 단결정 분 율의 향상뿐만 아니라 잉곳의 생산 단가를 저감시키는 노력들이 이루어졌다.

4) Mono-like 규소는 단결정과 유사한 효율과 다결정 과 유사한 생산 단가를 가지고 있지만 수율 및 대형화 면에서는 부족한 실정이다. 다결정 성장을 억제하기 위 한 seed의 형태, 놓이는 위치와 적용 방법 등에 따른 비 용에 의해 생산 단가가 증가되는 요인으로 작용하여 기 술 개발에 문제가 되고 있다. 또한 seed의 과다 용융으 로 인한 단결정 분율 감소와 다수의 결정립들의 존재는 수율의 감소를 야기시킨다. DS법으로 단결정 분율을 증 가시킬 수 있는 공정 조건(결정화 시간, 냉각 온도, melting 온도 등)의 변화를 통해 성장 조건을 찾아야 한
다고 판단된다. 만일 다수의 결정립들이 존재하더라도 그들이 쌍정 입계를 많이 포함하고 있다면 전기적 특성 에 영향을 미치지 않을 것이다. 따라서 단결정과 다결정 의 단점을 보완할 수 있는 mono-like 규소를 개발하기 위해서는 seed의 적용과 DS법을 적용한 공정 조건에 대 한 충분한 연구가 이루어져야 한다고 판단된다. 또한 최 근 적용되기 시작한 $\mathrm{HPmc}-\mathrm{Si}$ 의 기술이 TRPV 2013 (2014.3)에 따르면 2024년 p-type과 n-type HPmc-Si의 점유율이 $80 \%$ 에 이를 것이라 한다. 이 기술은 monolike 기술과 매우 유사한 방법이므로, mono-like 규소 결 정의 수율 및 품질 제어의 어려움에 있어 이 기술의 더 많은 연구가 이루어져 mono-like 규소 결정을 대체할 수 있도록 개발되어야 한다고 생각한다.

\section{감사의 글}

이 논문은 인천대학교 2011년도 자체연구비 지원에 의하여 연구되었기에, 이에 감사 드립니다.

\section{참 고 문 헌}

[1] K. Nakajima, R. Murai, K. Morishita and K. Kutsukake, "Growth of single bulk crystals with low oxygen concentrations by the noncontact crucible method using silica crucibles without $\mathrm{Si}_{3} \mathrm{~N}_{4}$ coating", J. Cryst. Growth 372 (2013) 121.

[2] J.D. Zook, "Effects of grain boundaries in polycrystalline solar cells", Appl. Phys. Lett. 37 (1980) 223.

[3] X. Tang, Laurent A. Fancis, L. Gong, F. Wang, J.R. Raskin, D. Flandre, S. Zhang, D. You, L. Wu and B. Dai, "Characterization of high-efficiency multi-crystalline silicon in industrial production", Sol. Energy Mater. Sol. Cells 117 (2013) v 225.

[4] K. Kutsukake, N. Usami, Y. Ohno, Y. Tokymoto and I. Yonenaga, "Control of Grain boundary propagation in Mono-like Si: Utilization of functional grain boundaries", Physics Express 6 (2013) 025505.

[ 5 ] H. Miyazawa, L.J. Liu, S. Hisamatsu and K. Kakimoto, "Numerical analysis of the influence of tilt of crucibles on interface shape and fields of temperature and velocity in the unidirectional solidification process", J. Cryst. Growth 310 (2008) 1034.

[6] B.C. Sim, Y.H. Jung, J.E. Lee and J.E. Lee, "Effect of the crystal-melt interface on the grown-in defects in silicon CZ growth", J. Cryst. Growth 299 (2007) 152.

[7] O.A. Noghabi, M. M'Hamdi and M. Jomaa, "Effect of crystal and crucible rotations on the interface shape of Czochralski grown silicon single crystals", J. Cryst. Growth 318 (2011) 173.

[ 8 ] X. Gu, X. Yu, K. Guo, L. Chen, D. Wang and D. Yang, "Seed-assisted cast quasi-single crystalline silicon for photovoltaic application: Towards high efficiency and 
low cost silicon solar cells", Sol. Energy Mater. Sol. Cells 101 (2012) 95.

[9] K. Nakajima, K. Morishita, R. Murai and K. Kutsukake, "Growth of high-quality multicrystalline $\mathrm{Si}$ ingots using noncontact crucible method", J. Cryst. Growth 355 (2012) 38.

[10] K. Fujiwara, W. Pan, N. Usami, K. Sawada, M. Tokairin, Y. Nose, A. Nomura, T. Shishido and K. Nakajima, "Growth of structure-controlled polycrystalline silicon ingots for solar cells by casting", Acta Materialia 54 (2006) 3191.

[11] B. Gao, X.J. Chen, S. Nakano and K. Kakimoto, "Crystal growth of high-purity multicrystalline silicon using a unidirectional solidification furnace for solar cells", J. Cryst. Growth 312 (2010) 1572.

[12] L. Raabe, O. Patzold, I. Kupka, J. Ehrig, S. Wurzner and M. Stelter, "The effect of graphite components and crucible coating on the behavior of carbon and oxygen in multicrystalline silicon”, J. Cryst. Growth 318 (2011) 234.

[13] H. Matsuo, R.B. Ganesh, S. Nakano, L.J. Liu, Y. Kangawa, K. Arafune, Y. Ohshita, M. Yamaguchi and K.
Kakimoto, "Analysis of oxygen incorporation in unidirectionally solidified multicrystalline silicon for solar cells", J. Cryst. Growth 310 (2008) 2204.

[14] G. Muller and J. Friedrich, "Optimization and modeling of photovoltaic silicon crystallization processes", Selected Topics on Crystal Growth 1270 (2010) 255.

[15] N. Stoddard, B. Wu, I. Witting, M. Wagener, Y. Park, G. Rozgonyi and R. Clark, "Casting single crystal silicon: novel defect profiles from BP solar's mono ${ }^{2 \mathrm{TM}}$ wafers", Solid State Phenomenon 131-132 (2008) 1.

[16] B. Gao, S. Nakano, H. Harada, Y. Miyamura, T. Sekiguchi and K. Kakimoto, "Reduction of polycrystalline grains region near the crucible wall during seeded growth of monocrystalline silicon in a unidirectional solidification furnace", J. Cryst. Growth 352 (2012) 47.

[17] C.W. Lan, "Recent progress of crystal growth modeling and growth control”, Chem. Eng. Sci. 59 (2004) 1437.

[18] W. Ma, G. Zhong, L. Sun, Q. Yu, X. Huang and L. Liu, "Influence of an insulation partition on a seeded directional solidification process for quasi-single crystalline silicon ingot for high-efficiency solar cells", Sol. Energy Mater. Sol. Cells 100 (2012) 231. 